\title{
1750 - A DEFINIÇÃo GEOGRÁFICA DO BRASIL
}

João José Planella*

Pouco mais de um século decorrera desde em que, levantando-se contra a política de Olivares, Portugal readquiria a sua independência.

Longo e difícil caminho fora até então trilhado, quer na Europa, quer no imenso império colonial. Na Europa, não foi apenas a luta contra os exércitos espanhóis, que obrigou a criar, praticamente, do nada, o exército português, para enfrentar os perigos de uma guerra, que, se resultasse em derrota, subordinaria efetivamente Portugal à Espanha, com o desaparecimento das características de uma monarquia-dual, que tinham sido regularmente respeitadas pelos dois primeiros Áustrias, para começarem a ser descumpridas na administração de Conde-Duque de Olivares, ministro todo-poderoso de Felipe III, de Portugal, IV de Espanha.

Portugal teve, também, que travar em toda a Europa uma ativa batalha diplomática, procurando apoio entre os adversários dos Habsburgos, mesmo que fossem alguns desses, como os holandeses, os principais autores e beneficiários do início da ruína do seu império na Ásia e já possuidores de vastas extensões de terra, conquistadas na América, e que não haviam detido ainda seu ímpeto expansionista. Viu-se Portugal tratado pela diplomacia do Cardeal Mazarino, não como um aliado, mas

* Professor aposentado do Departamento de História da PUCRS. Membro do Instituto Histórico de Pelotas-RS. 
como um elemento para contar com mais favoráveis condiçōes no seu tratado com a Espanha, viu-se também, por vezes, excluído das negociações de paz (Congresso de Cambrai) ${ }^{1}$.

As dificuldades e variaçōes nas relaçōes com a França, com a Espanha e com a Holanda, tinham obrigado a Portugal, no interesse da conservação do seu império colonial, a aproximar-se da Inglaterra, ainda que esta aliança lhe custasse a praça de Bombaim e acordos comerciais, bem favoráveis aos ingleses.

Não tinham sido poucas também as dificuldades encontradas, após a restauração em 1640, com a Corte Pontifícia, pois o provimento dos bispados, por indicação de D. João IV, correspondia a um reconhecimento pelo Papa de autonomia de Portugal, contra o que se exercia toda a pressão do embaixador espanhol, situação que perdurou até 1668 , quando a assinatura da paz entre Espanha e Portugal permitiu a normalização das relações entre Portugal e a Corte Pontifícia.

Todas estas circunstâncias adversas, superadas paulatinamente, haviam formado em Portugal um grande número de diplomatas, cuja visão e capacidade se comparavam aos melhores dos outros países europeus.

$\mathrm{Se}$, na Europa, fora esgotante a guerra armada e constante a luta diplomática, não menor fora a luta para conservação do império colonial, que começara a desfazer-se na última década do domínio espanhol.

"A multiplicação dos ataques e a escassez ou falta total de reforços vindos da Europa explicam os grandes desastres sofridos por Portugal a partir de 1630. A Espanha estava em guerra por toda a parte e precisava do dinheiro português. Não havia verbas bastantes para se construírem, equiparem e enviarem navios com exércitos e munições para onde quer que os Impérios Português e Espanhol sofressem ataques: no Brasil, na África, na Ásia. Pouca coisa se modificou, em boa verdade, desde 1500. Não temos provas de maior corrupção, maiores crueldades, menor organização ou menos bravura. Simplesmente, os inimigos eram agora demasiados e tão bem organizados e preparados como os portugueses e os espanhóis.

"Na década de 1630, a maior parte do Ceilão perdeu-se a favor da Holanda. Em 1639, foram os mesmos holandeses a bloquear Goa por vários anos. Depois da Restauração, os desastres acentuaram-se e aceleraram-se visto que o governo era obrigado a organizar a resistência na metrópole e 
dificilmente se podia permitir o envio de quaisquer reforços. Málaca capitulou ante os holandeses em 1641. Um armistício de dez anos (1641-1651) interrompeu o processo de declínio, que continuou a partir de 1651: grande número de feitorias e fortalezas na Índia renderam-se em 1653, Colombo perdeu-se em 1656, o resto de Ceilão dois anos mais tarde, depois Cranganor e Cochim (1662), finalmente Bombaim, cedida aos Ingleses em 1665. No entanto os Árabes auxiliados pelos Ingleses, forçaram Portugal a sair da Arábia e do Golfo Pérsico (1650). Na Indonésia e no arquipélago das Molucas tudo se desvaneceu, excetuada uma parte de Timor. No Japão as autoridades centrais expulsaram os mercadores portugueses e massacraram bom número de cristãos e missionários. Por volta de 1665 , e depois de vinte e cinco anos de desastres sucessivos, o outrora poderoso império da Ásia estava reduzido a Goa, Damão, Diu, Baçaim e meia dúzia de insignificantes fortalezas na Índia, a Macau na China e a metade de Timor na Indonésia."

"É precisso acentuar que o governo de Lisboa fora obrigado a uma escolha decisiva nas décadas de 1640 e 1650 , afim de salvar alguns quinhões fundamentais do Império. A escolha consistira em abandonar a Ásia a favor do Brasil e suas partes complementares africanas. Os Portugueses deram-se conta de que não tinham forças para resistir em todo o mundo. Acertadamente, escolheram a parte mais promissora, aquela onde a colonização branca se difundia com caráter definitivo e permanente e onde os benefícios comerciais podiam rivalizar com os proveitos em declínio do Oriente."2

Esta "escolha decisiva" foi cuidadosamente executada pelos monarcas portugueses da Dinastia de Bragança, dentro das condições e recursos de que dispunham. Aparentemente vacilante, sob D. João IV e Afonso VI, diante dos problemas com a guerra contra a Espanha, com D. Pedro II assumiria já um caráter diverso, francamente expansionista, como aparece com a fundação da Colônia do Sacramento. Contudo, seria no longo reinado de D. João V que esta política apareceria definindo-se em todos os setores e abrangendo as mais variadas formas:

"Ao longo de toda esta obra se verá que outra preocupação, a par daquelas, predomina, caracteriza e, por vezes, dramatiza e ensombra o seu reinado: a afirmação e a defesa da soberania portuguesa na América. Por ela D. João 
V mudou a política exterior de Portugal. Por ela teimou, contra o parecer de alguns de seus ministros e conselheiros, na conservação da Colônia do Sacramento, que mais tarde veio a tornar-se à chave das negociações do Tratado de Madri. Por ela promoveu a criação das dioceses de Mariana e São Paulo e, mais que tudo, das Prelazias de Goiás e Cuiabá, prévia sanção papal à ereção das Capitanias de Goiás e Mato Grosso."

"Por ela preparou durante quase vinte anos de pertinazes esforços um Novo Atlas do Brasil, não só de latitudes, mas de longitudes observadas por métodos astronômicos, juntamente prólogo e conseqüência do Tratado de Madri."3

A fundação da Colônia do Sacramento, em 1680, precedeu de pouco o verdadeiro ciclo do ouro, a fase essencialmente povoadora do interior de Minas, Goiás e Mato Grosso, tornando-se, em breve, um bastião importante para a defesa das minas, servindo, por outra, de proteção ao avanço do povoamento em direção ao sul.

O ciclo do ouro teria inúmeros efeitos demográficos, geográficos, econômicos, culturais e administrativos, alguns destes resultantes do próprio efeito dos quintos e, depois da capitação sobre a fazenda real.

"O ouro permitiu a D. João V - e é o que iremos ver e se desconhece inteiramente - presidir à preparação científica do Tratado de Madri, ou melhor à renovação da cultura geográfica, astronômica e cartográfica do país, o que iria dar a Alexandre de Gusmão a possibilidade de assentar o novo convênio sobre a negação do Tratado de Tordesilhas. $\mathrm{O}$ ouro permitiu-lhe formar o escol de engenheiros, astrônomos e cartógrafos, que durante o seu reinado e no seguinte iriam fortificar e cartografar, não só as costas, mas as fronteiras terrestres do Brasil, fato essencial para a compreensão da história luso-brasileira, nesse período."

"Com o ouro renovou ou fundou praças e fortalezas ao longo de toda a costa do Brasil, e sobretudo desde o Rio de Janeiro para o sul, onde se construíram, sob as ordens dum dos melhores e mais experimentados engenheiros portugueses, José da Silva Pais, as defesas da Ilha de Santa Catarina e os fortes do Rio Grande e São Miguel."

"Com o ouro, enfim, recrutou na Itália, Alemanha e Suíça, as dezenas de engenheiros, geógrafos, astrônomos e 
cartógrafos que haviam de realizar no terreno o tratado, negociado em 1750."4

Esta preparação de engenheiros iniciara-se em 1647 com a criação da "Aula de Fortificações e Arquitetura Militar", em que se distinguiu Luís Serrão Pimentel, que acumulava ao cargo de professor da mesma o de Cosmógrafo-mor do Reino e, posteriormente, com o de Engenheiromor. Seu Método Lusitânico de Desenhar Fortificações, publicado postumamente, em 1681, marca o início do desenvolvimento da engenharia militar em Portugal, que estivera durante muito tempo estagnada em virtude do domínio espanhol, justamente numa época em que a evolução constante das armas de fogo impunha a necessidade de contínuas modificações nessa arte, enquanto na Itália, na Espanha e na Holanda desenvolvia-se a ciência da fortificação. A construção do Forte de São Filipe, na foz do Rio Sado, nas imediações de Setúbal, durante o domínio espanhol teria uma sensível influência sobre esse início do desenvolvimento da engenharia portuguesa. Mas essas escolas iriam logo ser superadas pela escola francesa, com as fortificaçōes segundo o plano de Vauban. Mas a renovação efetiva da Engenharia portuguesa foi sobretudo obra de Manuel de Azevedo Fortes, nomeado em 1719 para o cargo de Engenheiro-mor do Reino.

"que de resto estava em condições de desempenhar cabalmente, como o provou pela atividade desenvolvida ao exercêlo. Logo no ano imediato desta nomeação fazia imprimir uma 'Representação sobre o Modo e Direção que devem ter os Engenheiros', que é como um projeto de regulamento para o exercício das atividades da engenharia; alguns anos depois (1728-1729) publicou $O$ Engenheiro Português, obra em dois volumes e de caráter didático, contendo uma exposição sistemática dos conhecimentos considerados essenciais ao engenheiro, sem esquecer, como então era de uso, os utilizados para fins militares, sobretudo certas noções de fortificação. Antes dessa obra publicara também um Tratado sobre o modo mais fácil e mais correto de fazer as Cartas Geográficas. (Lisboa, 1722), que, apesar de ser essencialmente uma compilação, não pode ser esquecida na história da cartografia portuguesa." 
Tendo recebido de $\mathrm{D}$. João $\mathrm{V}$ todo o apoio para a reforma de estudos da Academia Militar, a atuação de Azevedo Fortes criava uma escola na engenharia portuguesa e, acrescendo-se a isto, imprimia um rumo prático, efetivo e dinâmico à cartografia portuguesa, ela também em plano modesto, desde o desaparecimento da notável geração de cartógrafos do século anterior, representados sobretudo por João Teixeira de Albernaz.

"Já veremos que - fato, segundo cremos, desconhecido a Azevedo Fortes cabe a honra de ter iniciado o levantamento topográfico e Portugal antecipando assim a sua pátria a muitos países europeus."

Os resultados colhidos dessa sua atuação eram de tal ordem que se dirige ao rei de Portugal, nos termos seguintes, que refletem, ao lado da satisfação pelo nível atingido, a segurança na orientação adotada em seu trabalho:

“... não só os mesmos Engenheiros, mas também a maior parte dos Praticantes da Academia Militar se acham capazes de fazer exatamente, e com toda a propriedade as cartas de qualquer País, ou sejam de grande ou de pequena extensão".?

Foi, sem dúvida alguma, de considerável importância para o Brasil, esse surto da engenharia portuguesa, que coincidia com a nova fase de expansão territorial não mais no sentido litorâneo, mas na ocupação do interior. Ouvindo Jaime Cortesão, mestre consumado da História nas suas bases cartográficas:

"De qualquer forma reputamos aqueles trabalhos de Azevedo Fortes e dos seus discípulos um dos fatos capitais para se compreender a história da formação territorial do Brasil, nos anos que vão seguir-se por mais de meio século. As Academias Militares sob o impulso do Engenheiro-mor e a proteção, ainda que inconstante de D. João V, tornaram-se um viveiro de engenheiros, geógrafos e cartógrafos, onde vão sair os grandes construtores de Mato Grosso, como o seu primeiro governador D. Antônio Rolim de Moura, e Luís de Albuquerque Pereira e Cáceres, e do Rio Grande do Sul como José da Silva Pais, André Ribeiro Coutinho, Sá e Faria e Alexandre José Montanha". 
"Mais e melhor contribuíram para a formação de um novo tipo social e cultural, que as necessidades da época exigiram."

"Mas num e noutro caso, da expansão marítima e da terrestre, causa e efeito mudam rapidamente de sentido. $\mathrm{O}$ que foi determinado passa a determinar. $\mathrm{O}$ engenheiro, que nasceu da expansão, passa a criar, dirigir, medir e consolidar a expansão."

"Desde 1730, começa a desenhar-se esse tipo social em Portugal. A grande expansão bandeirante, a que leva ao alto Paraguai, é conhecida na Metrópole apenas em 1719. Passados poucos anos já os aprendizes de Engenheiros afluíram às Academias Militares, oficiais e particulares."

"Sem a inclusão deste fato na História do Brasil, é impossível compreender a sua formação territorial, na primeira metade do século XVIII. Quinze ou dez anos antes da celebração do Tratado de Madri, todos os postos chaves do Brasil, ou são ocupados por engenheiros, ou por governadores que se fazem acompanhar de engenheiros ou cartógrafo. $\mathrm{O}$ Vice-Rei Conde das Galveias tem ao seu lado e utiliza, em numerosas missōes, um engenheiro e cartógrafo francês, Frei Estevão de Loreto; Gomes Freire de Andrade, o governador do Rio e das províncias do Sul, ele próprio imbuído de novo espírito cultural, tem como auxiliar direto, o engenheiro e cartógrafo, mestre de engenheiros e cartógrafos, José Fernandes Pinto Alpoim; o governador do Maranhão-Pará, Francisco Pedro de Mendonça Gorjão, tem por auxiliar o sargento-mor, geógrafo e cartógrafo, José Gonçalves da Fonseca; o governador de Santa Catarina e fundador do Rio Grande, espécie de fronteiro-mor do Sul, é o brigadeiro José da Silva Pais; o Conde dos Arcos leva para a sua Capitania de Goiás o geógrafo e cartógrafo Francisco Tosi Colombina; e, na fronteira oeste, D. Antônio Rolim de Moura, governador de Mato Grosso, é ele também engenheiro, astrônomo e cartógrafo."

"De todos estes homens, o que se aproxima mais do ideal de engenheiro setecentista em que se fundem o técnico, o político e o organizador, é José da Silva Pais, que constrói fortalezas, desenha mapas e funda províncias. Mas trata-se apenas do tipo, mais plenamente realizado, duma forma de vida nacional, de múltiplos aspectos." 
Entretanto, ainda que grande o desenvolvimento da Academia Militar, e o auxílio prestado pelas da Bahia e do Rio de Janeiro, eram os engenheiros insuficientes para todo o trabalho que se lhes exigia no Brasil, reclamando, muitas vezes, os governadores que o governo da Metrópole os enviasse ao Brasil. Para suprir esta falta também recorreu D. João V à contratação no estrangeiro de elementos para suprir as deficiências nesse setor:

"Não foram poucos os estrangeiros que chamou a Portugal, ...... arquitetos, músicos, pintores e gravadores, ....... "Observemos apenas que não foram em números menor os engenheiros, os militares, os geógrafos, os astrônomos, cartógrafos e matemáticos que contratou no estrangeiro e subsidiou com mão régia para os utilizar na cultura portuguesa e na aplicação das técnicas necessárias à expansão. Lembremos por agora apenas os nomes mais notáveis, daqueles cuja personalidade se acha intimamente ligada à história ultramarina, portuguesa e, mais em especial, ao Brasil: $\mathrm{O} \mathrm{Pe}$. Domingos Capacci, astrônomo e cartógrafo, o engenheiro Frederico Jacob de Weinholtz, instrutor e inventor de novas peças de artilharia; Frei Estevão de Loreto, engenheiro e cartógrafo; o engenheiro Carlos Mardel; o coronel Miguel Ângelo Blasco, engenheiro e cartógrafo; o astrônomo e cartógrafo Miguel Ciera, o cartógrafo e engenheiro Schwebel, os astrônomos Brunelli e Stzentmartony, os engenheiros e cartógrafos Galuzi e Sturmm, etc." ${ }^{10}$

Isto sem contar os que, muito antes das negociaçōes do Tratado de Madri, haviam sido contratados no estrangeiro e conservados em Portugal depois de longa permanência de trabalhos no Brasil, como o engenheiro francês, Brigadeiro João Massé, já tantas vezes citado. Mas a realidade é que, no início das negociações do Tratado de Madri eram bem deficientes as indicações cartográficas de que dispunham os negociadores.

Estas deficiências de documentação cartográficas já há muito haviam sido observadas e estavam sendo sentidas. Já em 1722, Diogo de Mendonça Corte Real dirigia-se ao Conde de Tarouca, em Paris, transmitindo-lhe ordens de D. João V para comprar um Atlas Generalis em 103 volumes, 17 contendo especialmente peças iconográficas, que Jaime Cortesão identifica como o Atlas de Boendermaker. ${ }^{11}$ Também, em 
1736, D. Luís da Cunha, em carta datada de Haia, em 14 de Setembro, fala da remessa de uma carta holandesa sobre o rio da.Prata. ${ }^{12}$

Esta deficiência de cartas portuguesas tinha já determinado a contratação dos já citados "padres Matemáticos", Capacci e Soares, e exigiria, posteriormente, novos e especiais cuidados.

Mas, se a documentação cartográfica do conjunto das vastas regiões de fronteiras, na América, dos domínios das Coroas portuguesa e espanhola eram deficientes, eram, pelo contrário, numerosas as fontes de informações dos relatos monçoeiros, dos governadores, constituindo-se em base importantíssima para o delineamento de uma política firme na fixação dos limites, especialmente quando as descobertas das comunicações do Tocantins com a região das minas de Goiás e das possibilidades de contato entre as bacias do Amazonas e do Prata requeriam cuidados especiais para defesa das regiōes auríferas.

A política de $\mathrm{D}$. João $\mathrm{V}$ de aproximação com a Espanha cuidadosamente desenvolvida durante o reinado de Felipe V, apesar das influências antiportuguesas existentes na corte espanhola, estimuladas principalmente pela rainha Isabel Farnésio, iriam alcançar êxito com a subida ao trono do rei Fernando VI, genro do soberano português, monarca de índole pacífica e profundamente influenciado por sua esposa, ocorrida em 1746.

As negociações teriam início nesse mesmo ano, depois da chegada a Madri do plenipotenciário nomeado, D. Tomás da Silva Teles, Visconde de Vila Nova da Cerveira, em 29 de Setembro, chegando no dia seguinte a Lisboa o novo embaixador espanhol D. Jaime Mazores de Lima, Duque de Souto Mayor e Grande de Espanha. Em Madri, era plenipotenciário espanhol D. José Carvajal y Lencaster, ministro de Fernando VI.

Não cabe aqui a narração pormenorizada das negociações do Tratado, longas e cuidadosas, sucedendo-se propostas e contra-propostas, até a elaboração da redação final, pois são numerosas as obras a respeito das mesmas, bem como as análises do Tratado, especialmente a monumental obra de Jaime Cortesão, Alexandre de Gusmão e o Tratado de Madri, em 9 tomos, com soberba documentação, além de percuciente análise de todos os seus aspectos.

"Entre D. João V, Rei de Portugal, e D. Fernando VI, Rei de Espanha, foi assinado, em Madri, aos 13 de Janeiro de 1750 , o Tratado de limites das conquistas, ‘que ha sido', lembra 
Cantillo, 'indubitablemente el tratado más proprio para se estabelecer una solida y durable armonia entre las dos coronas'. 'O estudo do Tratado de 1750', disse o Barão do Rio Brano, 'deixa a mais viva e grata impressão de boa fé, lealdade e grandeza de vistas que inspiraram esse ajuste amigável de antigas e mesquinhas querelas, consultando-se unicamente os princípios superiores da razão e da justiça e as conveniências da paz e da civilização da América'. Roberto Southey assim aprecia o Tratado de 1750: 'A linguagem e o teor geral deste memorável Tratado estão dando testemunho da sinceridade e boas intenções das duas cortes. Parecem, na verdade, os dois soberanos contratantes ter-se adiantado ao seu século'.

"O Tratado de 13 de Janeiro de 1750, foi negociado ostensivamente e assinado, por parte de Portugal, por Tomás da Silva Teles, mas 'quem de fato defendeu a causa de Portugal e do Brasil e os interesses bem entendidos da América nesse debate foi o célebre estadista e diplomata brasileiro Alexandre de Gusmão'."13

É compreensível este fato de ter cabido a Alexadre de Gusmão tão relevante papel, que faz dele o verdadeiro mentor e responsável pelo Tratado de Madri. Distinguira-se sempre D. João V por uma ingerência direta em todos os negócios do governo, especialmente nos relacionados à política externa. Sob seu governo seria impossível aparecer um ministro com a amplitude de poderes que caracterizariam, no governo de seu sucessor, a figura do ministro onipotente que foi Pombal. Mas sofrera, em 1742, um derrame cerebral que pela paralisia resultante, trouxe uma diminuição acentuada de sua atividade. Cresceu aí a importância de Alexandre de Gusmão que, então exercia o cargo de secretário particular do rei com exclusividade nos assuntos da política externa. Deste 1719 exercera diversas funções e embaixadas, revelando-se hábil negociador, sabendo entretanto manter uma linha de firme intransigência. Conquistara a amizade e a confiança de D. João V, que o chamou, em 1731, para o cargo que exerceria ininterruptamente até a morte do monarca. Desta maneira coube-lhe inteiramente a orientação dos negociadores portugueses do Tratado de Madri, destinado a fixar as fronteiras da terra em que nascera e à qual dedicara sempre uma especial atenção. Coube-lhe a responsabilidade de traçar como ponto de partida das negociações o abandono do Meridiano de Tordesilhas e a aplicação dentro do Direito 
Internacional do princípio do uti possidetis do Direito Romano. Sua vasta correspondência mostra a participação ativa que teve influenciando quase toda a redação do Tratado. Mesmo os móveis ocultos que orientaram sua atuação vieram por ele a ser revelados. Afastado, pela morte de D. João $\mathrm{V}$, do cargo que tão brilhantemente exercera, viu sua obra atacada pelo herói da defesa da Colônia do Sacramento, o antigo governador Antônio Pedro de Vasconcelos, e pela má vontade de Sebastião José de Carvalho e Melo, chamado pelo novo soberano, D. José I, para o ministério o que, em breve, se tornaria o verdadeiro governante de Portugal. Atacado o Tratado e levantadas suspeitas quanto à sua atuação, foi Alexandre de Gusmão obrigado a publicar sua defesa, que lança extraordinária luz sobre o Tratado e sobre a orientação das suas negociaçōes, constituindose no maior título desse eminente santista.

Compreende o Tratado de Madri uma longa introdução, que se constitui, inicialmente numa exposição de motivos, princípios e diretivas do Tratado que deveria ser o ponto de partida para o estabelecimento de relações cordiais e pacíficas na América.

"Os Sereníssimos Reis de Portugal e Espanha, desejando eficazmente consolidar e estreitar a cordial e sincera amizade, que entre si professam, consideraram que o meio mais conducente para conseguir tão saudável intento, é tirar todos os protextos, e alhanar os embaraços que possam ao diante alterá-la, e particularmente os que possam oferecer com o motivo dos Limites das duas Coroas na América, cujas Conquistas têm adiantado com incerteza e dúvida, por não se haverem averiguado até agora os verdadeiros Limites daqueles Domínios, ou a paragem donde se há de imaginar a Linha divisória, que havia de ser o princípio inálterável da demarcação de cada Coroa." ${ }^{14}$

Segue-se as alegações de Portugal e as da Espanha a respeito dos pontos em que as ocupações de outro contratante desobedeciam à linha ajustada em Tordesilhas, como o caso da ocupação das Filipinas e de outras ilhas do Pacífico pelos espanhóis, e o da fundação da Colônia do Sacramento, e ocupação de terras do vale amazônico, além das regiões do Mato Grosso, pelos portugueses, acrescentando o protesto contra a interpretação, atribuida no Tratado ao governador de Buenos Aires, de limitar a um tiro de canhão o território correspondente à Colônia do Sacramento, devolvida aos portugueses pelo Tratado de Utrecht. 
Após essas alegações, partem para as razões que levariam à anulação da demarcação estabelecida em Tordesilhas e os novos princípios que se deveriam aplicar para a demarcação dos limites:

“... como também pela impossibilidade moral de estabelecer com certeza pelo meio da mesma América uma Linha Meridiana; e finalmente por outros muitos embaraços, quase invencíveis, que se ofereceriam para conservar sem controvérsia, nem excesso, uma demarcação regulada por Linhas Meridianas: e considerando ao mesmo tempo, que os referidos embaraços talvez, foram pelo passado a ocasião principal dos excessos, que de uma e outra parte se alegam, e das muitas desordens que perturbaram a quietação de seus Domínios; resolveram pôr termo às disputas passadas e futuras, e esquecer-se, e não usar de todas as ações e direitos, que possam pertencer-lhes em virtude dos referidos Tratados de Tordesilhas, Lisboa, Utrecht, e da Escritura de Saragoça, ou de outros quaisquer fundamentos que possam influir na divisão dos seus Domínios por Linha Meridiana; e querem que ao diante nāo se trate mais dela, reduzindo os Limites das duas Monarquias aos que se assinalarão no presente Tratado; sendo o seu ânimo, que nele se atenda com cuidado a dois fins: O primeiro e mais principal é, que se assinalem os Limites dos dois Domínios, tomando por balizas as paragens mais conhecidas, para que em nenhum tempo se confundam, nem dêem ocasião a disputas, como são a origem, e curso dos rios, e os montes mais notáveis: $\mathrm{O}$ segundo, que cada parte há de ficar com o que atualmente possui; à exceção das mútuas cessões, que em seu lugar se dirão; as quais se farão por conveniência comum, e para que os Confins fiquem, quanto for possível, menos sujeitos a controvérsias." 15

Firmava-se assim o uti possidetis, como princípio básico na fixação dos limites, que asseguraria juridicamente a posse da Amazônia e das regiōes do Brasil central, ocupadas fora da delimitação fixada em Tordesilhas, ainda que a mesma tivesse partido de determinação de um soberano que governava simultaneamente as duas nações: Felipe III, de Portugal, VI da Espanha.

Compreende depois o Tratado de Madri 26 artigos, que se dividem nitidamente em três partes. Os três primeiros estabelecem o direito das duas Coroas a determinadas regiōes, dentro do princípio de posse fixado no preâmbulo. 
Assim, no art I, determina:

"O presente Tratado será o único fundamento, e regra que ao diante se deverá seguir para divisão, e Limites dos dois Domínios, em toda a América, e na Ásia; ...."16

fixando, no Art. II, os territórios que pertencerão à Espanha, pelo direito de posse:

"As Ilhas Filipinas, e as adjacentes que possui a Coroa da Espanha, lhe pertençam, para sempre, sem embargo de qualquer pretenção, que possa alegar-se por parte da Coroa de Portugal,..."17

No Art, III, estabelece o que passa juridicamente à posse da Coroa de Portugal:

"Da mesma forma pertencerá à Coroa de Portugal tudo o que tem ocupado pelo rio das Amazonas, ou Marañon acima e o terreno de ambas as margens deste rio até as paragens, que abaixo se dirão; como também tudo o que tem ocupado no distrito de Mato Grosso, e dele para a parte do Oriente, e Brasil, sem embargo de qualquer pretenção, que possa alegar-se por parte da Coroa de Espanha,..."18

A linha divisória era fixada nos artigos seguintes, de IV a $\mathrm{X}$. Iniciava-se na barra do regato nascido no Monte de Castilhos Grande, e deste seguia pelos divisores de águas das bacias da Lagoa Mirim e do Rio da Prata, passando pelas cabeceiras do Rio Negro e, daí, até as nascentes do Ibicuí, continuando por este até desembocar no Uruguai (Art. IV). Subia o Uruguai até a foz do Peipiri ou Pequiri, acompanhando este até sua nascente até a nascente do rio mais próximo que desembocasse no Iguaçu ou Rio Grande de Curitiba (sic), descendo por este até seu encontro com o Rio Paraná e, subindo por este, até a foz do Igureí (Art. V). Do Igureí prosseguiria pelo rio mais próximo que desembocasse no Paraguai, subindo-o até a foz do Jauru (Art. VI), cuja navegação seria privativa dos portugueses e de onde, uma reta buscaria o Rio Guaporé, na confluência com o Rio Sararé, por ele continuando até o Rio Madeira, caminho que ficaria privativo dos portugueses (Art. VII), por ser a ligação usada com o Amazonas. Uma linha reta daí partiria até o Rio Javari, 
continuando a fronteira por este até lançar no Amazonas, que desceria até a foz do Rio Japurá (Art. VIII). Subiria o Rio Japurá até a cadeia de montes que separam as bacias do Orenoco e Amazonas, prosseguindo por ela para o oriente (Art. IX). As ilhas dos rios, que servissem de limite, seriam consideradas como pertencentes ao proprietário da margem mais próxima durante a estação seca (Art. X).

Se forem comparados os termos do Tratado de Madri com os do Tratado de Santo Ildefonso (10-10-1777), será notada uma reprodução quase literal dos artigos de números $\mathrm{V}$ a IX do primeiro nos artigos VIII a XII do segundo, sendo o artigo X do Tratado de Madri modificado no de Santo Ildefonso quando a ilha for de grandes dimensões. Assim, a única modificação essencial correspondia ao Art. IV, que ficava anulado, desaparecendo a cessão do território das Missões.

Os artigos restantes regularam questões decorrentes do traçado dessa extensa e nova linha de limites, especialmente quanto às cedências previstas e à forma como seriam feitas, proíbem o contrabando e a passagem por terra entre um domínio e outro, estabelecem critérios sobre a navegação dos rios e determinam que os Montes situados na raia divisória não poderão ser nem fortificados, nem povoados, pelos países contratantes. A proibição do erguimento de fortificações repete-se no artigo que estabelece a navegação comum de determinados rios.

Dois artigos (XI e XXII) tratam da aplicação prática do Tratado, assim:

"Art. XI - Ao.mesmo tempo que os Comissários nomeados por ambas as Coroas forem assinalandos os Limites em toda a Fronteira, farão as observaçōes necessárias para formar um Mapa, individual de toda ela; do qual se tirarẫo as cópias, que parecerem necessárias, firmadas por todos, que se guardarão nas duas Cortes para o caso que ao diante se ofereça alguma disputa, pelo motivo de qualquer infração; ..."

"Art. XXII - Para que se determinem com maior precisão, e se haja lugar à mais leve ao futuro nos Lugares, por onde deve passar a Raia em algumas partes, que não estão nomeados e especificadas distintamente nos Artigos antecedentes, como também para declarar a qual dos Domínios hão de pertencer as ilhas que se acharem nos rios que hão de servir de Fronteira, nomearão ambas as Majestades, quanto antes, Comissários inteligentes: os quais visitando toda a Raia, 
ajustem com a maior distinção e clareza as paragens, por onde há de correr a demarcação, em virtude do que só expressa neste Tratado, pondo marcos nos lugares, que lhes parecer conveniente; e aquilo em que se conformarem, será válido perpetuamente em virtude da Aprovação e Ratificação de ambas as Majestades"19

Há um artigo que mereceu sérios reparos na época e que se tornou causa da denominada "Guerra Guaranítica". Foi o Art. XVI, que estabelecia para as regiōes cedidas pelo Rei da Espanha (Território das Missões) e pelo Rei de Portugal (nas margens dos rios Pequiri, Guaporé e Amazonas) do deslocamento das populações para outra área dos domínios do seu soberano. A parte relacionada ao território das Missões prescreve:

"Das Povoações ou Aldeias, que cede Sua Majestade Católica na margem oriental do rio Uruguai, sairão os Missionários com todos os móveis e efeitos levando consigo os índios para os aldeiar em outras terras de Espanha; e os referidos índios poderão levar também todos os seus bens móveis e semoventes, e as Armas, Pólvora, e Muniçōes, que tiverem em cuja forma se entregarão as Povoações à Coroa de Portugal com todas as suas Casas, Igrejas, e Edifícios, e a propriedade, e posse do Terreno."20

Estas disposições não eram senão decorrência da própria cedência, mas representavam uma violência para as populações lá estabelecidas e a destruíção prática de todo o esforço realizado pelos missionários, que procuraram alcançar a anulação deste artigo e da cedência que o determinava. Esta resistência teria conseqüências mais profundas do que lhes seria possível imaginar, pois foi um dos motivos da política de luta de Pombal contra a Companhia de Jesus.

Disposição interessante pelos seus objetivos, porém dificílima de obter por efeito de um Tratado, e a estabelecida no Artigo XXI, que procurava fazer da América Meridional uma espécie de "zona neutra":

"Sendo a guerra ocasião principal dos abusos e motivo de se alterarem as regras mais bem concertadas querem Suas Majestades Fidelíssima, e Católica, que se (e que Deus não permita) se chegasse a romper entre as duas Coroas, se mantenham em paz os Vassalos de ambas, estabelecidos em 
toda a América Meridional, vivendo uns e outros como se não houvera guerra entre os Soberanos, sem fazer-se a menor hostilidade, nem por sí sós, nem juntos com os seus Aliados. E os motores e cabos de qualquer invasão, por leve, que seja, serão castigados com a pena de morte irremissível; e qualquer presa que fizerem, será restituida de boa fé, e inteiramente...,21

Concluía-se o Tratado com uma verdadeira aliança, com o estabelecimento da obrigação de mútuo socorro, tanto em relação a inimigos externos, como no caso de rebelião surgida nos domínios do outro soberano, pois as novas idéias, que tinham começado a surgir na Europa, já começavam a querer aflorar na América (Art. XXV).

É interessante observar o que expressam as primeiras linhas do Art. XXIV:

"Declara-se, que as cessões conteúdas nos presentes Artigos, não se reputarão como determinado equivalente umas de outras, senão que se fazem respeitando no total do que se controvertia e alegava, ou reciprocamente se cedia,..."22

Parece que esta "declaração" visava apenas às possíveis conseqüências diplomáticas futuras, pois, em relação ao passado, estava bem claro que Portugal teria já cedido a Colônia do Sacramento se lhe fosse proporcionada, em troca, uma região que pudesse ser considerada de equivalente importância. Na realidade houvera uma troca, mas, com esta declaração, a dificuldade que pudesse ser encontrada para a posse de uma das regiões, não envolveria forçosamente a desistência da outra.

Se, hoje, o Tratado de Madri aparece como a mais feliz realização da diplomacia portuguesa em relação aos seus domínios na América, ainda que muitos historiadores de língua espanhola o apontem como o mais inexplicável equívoco da diplomacia espanhola pela renúncia à soberania de imensas regiōes, recebendo em troca a insignificância da Colônia do Sacramento, que se erguia em território indiscutivelmente seu, é conveniente relembrar que esse Tratado foi mal recebido na Espanha, na América e, mesmo, em Portugal.

"En 1750 se concertó un tratado con Portugal, por el qual se le cedía Ibicuy, zona de 500 leguas en les misiones 
jesuitas del Paraguay, a cambio de la colonia del Sacramento, foco de contrabando y motivo de continuos conflictos con Portugal. Los jesuitas se pusieran al tratado y Carvajal y Lancáster murió sin verlo cumplido, siendo substituido por Ricardo Wal, un irlandés que estaba al servicio de España. "Ensenada, creyendo perjudicial para España el convenio, informó secretamente del asunto al hermano del monarca Carlos, entonces rey de Nápoles, presunto heredero de la corona de España, pues Fernando no tenía hijos, para que protestase del tratado. Ensenada fue destituido y desterrado, siendo su caída con regocijo en Londres, y el P. Rábago dejó de ser confesor del rey por su inteligencia con los jesuitas del Paraguay."(461)

O Marquês de la Ensenada, D. Zenón de Somodevilla y Bengoechea, que fora um dos mais notáveis ministros de Fernando VI, opusera-se ativamente ao Tratado, durante as negociações, tendo conseguido, ao menos, predispor contra ele o futuro rei Carlos III, que, de comum acordo com Pombal, o anularia pelo Tratado de el Pardo, de 12 de fevereiro de 1761.

Também na América o descontentamento se manifestou, tanto na região platina por parte dos Jesuítas do Paraguai e do governo de Buenos Aires, como na região amazônica, destacando-se nesta o parecer contrário do notável sertanista Joâo de Sousa de Azevedo, responsável pela abertura efetiva do caminho fluvial entre Mato Grosso e Pará, para a sua atividade comercial e que acompanhara a expedição já citada, enviada pelo governador do Estado do Maranhão e Grão Pará, que fez o levantamento cartográfico do Rio Madeira, aliás um dos poucos subsídios cartográficos de que dispuseram os negociadores do Tratado de Madri.

Foi tal a repercussão em Belém provocada pela notícia do Tratado de Madri que o governador Francisco Pedro de Mendonça Gorjão convocou uma reunião, para a qual foi convidado João de Sousa Azevedo, cujo parecer, datado de 16 de janeiro de 1752 , é inteiramente contrário ao Tratado. Demasiado longo para permitir transcrição e entrando em minúcias inteiramente ligadas à época (A expulsão dos jesuítas pela Espanha fez desaparecer inteiramente muitas das Missões então existentes no território boliviano, sem deixar traços) e que exigiriam também o conhecimento direto dos locais, não deve, entretanto, ser esquecido. Diz Souza Azevedo: 
"Sendo eu chamado para uma conferência ao Colégio de Santo Alexandre desta Cidade do Pará pelo Exmo. Senhor General Francisco Pedro de Mendonça Gorjão, que nesse tempo governava este Estado, em que se acharam presentes o dito Senhor, e os RR.PP. da Companhia de Jesus, o R.P. Reitor do dito Colégio Júlio Pereira, e o R.P. João de Sousa, e o R.P. Carlos Bretano, e seu companheiro ambos Espanhóis cientes na Matemática, que haviam descido pelo Rio dos Solimões para a Europa e entrando na conferência das Reais Divisões do Novo Tratado, vi alguma parte das condições, que expressava dos Reais Domínios de Suas Majestade, com os de Sua Majestade Católica, e acho estar ... (falta) ... prejuízo da Real Coroa Portuguesa, por alguma pequena experiência de parte, que tenha corrido, das Conquistas, e a experiência mostra." 24

Depois de apreciar a linha divisória, desde o Monte Castilhos Grande, chega à parte que pessoalmente conhece por ser a área de sua atividade:

"Manda o Tratado, depois de sair ao Paraguai por cima das sete correntes, navegar pelo Rio acima, até dar na barra do Rio Jauru, ficando a parte Oriental para Portugal, e a Ocidental para Castela." "Advertindo que estão os Portugueses de posse de uma, e outra margem, s'a souberem conservar, desde a barra do Rio Bothetiú (hoje, Miranda) para cima, que é até o nascimento do Paraguai, e seus braços, adonde tem ouro descoberto, e diamantes com limitação, e também há braço do Paraguai, chamado Rio Sepotuba, achei ouro com pouca quantia, ..., e três dias abaixo da barra do Rio Bothetiú foram os Portugueses conquistar o Gentio Paiaguases..." 25

Anota Virgílio Correa Filho:

"Na interpretação do Tratado de Limites, João de Sousa, naturalmente refletindo idéias correntes entre os seus patrícios, pleiteava a exclusividade de navegação do Paraguai para os súditos de Portugal, como depois sustentaria o capitão general Antônio Rolim de Moura, e com mais ardor, o mais arguto dos seus sucessores, Luís de Albuquerque de Melo Pereira e Cáceres." 26

Como para o Rio Paraguai, também afirma a posse portuguesa das duas margens do Rios Jauru e Guaporé: 
“O Rio Jauru, e Guaporé, tem sido povoados d'ambas as suas margens pelos Portugueses, que na Ilha Comprida o mesmo Guaporé, conservam um arraial proximamente queimado pelos R.P. Espanhóis.",27

Não param aí as restrições opostas pelo sertanista:

"Daí manda o Tratado botar um rumo de Leste para Oeste, até sair ao Rio dos Solimões, abaixo das duas Missões dos R.P. Carmelitas; e manda puxar os Marcos, que Pedro Teixeira, Capitão Mor pôs, em tempo da sujeição de Portugal a Castela, para cuja diligência foram desta Cidade 270 canoas, com número notável de índios e de infantaria (que pela maior parte morreu na expedição) e os Marcos ficaram assentados por ajuste, e consentimento dos Espanhóis precedendo ordens aos atos possessórios, cujos documentos se hão de achar no Arquivo desta Cidade. Mudados os Marcos, perderá Portugal 80 ou 100 léguas de terras em toda distância..... e sendo assim, como deve ser, apanhará Castela o melhor de 30 Missões, segundo presumo;"28

A conclusão a que chega o sertanista pioneiro expressa em poucas linhas, num incisivo julgamento:

"O novo Tratado está todo a favor de Espanha que dá as intrusas Missões do Rio Guaporé, sobre que há muitos anos dão contas à Sua Majestade os moradores de Mato Grosso, sem delas resultar determinação alguma; até agora tem ido quatro, e brevemente irão mais," 29

O documento de João de Sousa Azevedo impressiona pela segurança de conhecedor da região e pelo tom franco que manifeta, mais ainda, talvez, pela noção, que poderia ser classificada de "geopolítica" que insere na parte final do seu parecer:

"O rio da Prata, e o Amazonas, são as chaves de todo o Brasil, e o da Prata da navegação até dentro as Minas da Juruoca, e do Rio Verde, Vila de São João d'el-Rei, e Vila de São José." 30

Seria impossível que não ocorressem, ao longo da imensa linha de limites, semelhantes fatos de desconhecimentos pela Corte portuguesa das regiōes já em posse de seus vassalos, não só por ainda não estar instalado o primeiro governo da já criada Capitania de Mato Grosso, como pelo aspecto muitas vezes transitório do povoamento naquelas 
longínquas regiões. Mas, o próprio Tratado, deixando aos Comissários a responsabilidade de executar, no local, o cumprimento dos princípios diretivos apontados na declaração inicial, permitiria a sua correção.

Se, na Amazônia, o Tratado era recebido com restrições, muito maiores seriam as levantadas no sul pelos espanhóis. São praticamente unânimes os informes de origem platina na condenação à política espanhola da época:

"De donde resultaba que Portugal, cuyos avances sobre dominios españoles de América desde el Amazonas hasta el Plata, eran notorios y habían sido cumplidos casi siempre a mano armada y sobre problaciones españolas indefensas, convertía esos mismos hechos, contrarios a toda idea de equidad, en derechos ahora indiscutibles por condescendencia del monarca español. Olvidaba Fernando VI (o no lo sabía), que las conquistas de la casa de Austria en el Río de la Plata, no fueron como las conquistas de mamelucos y bandeirantes del Brasil en América, y aceptaba implícitamente que, de invocar sus derechos legítimos, Portugal pudiera esta vez, atribuyéndose 'conomiciento práctico' de la línea de Tordesilhas, decirle que la Filipinas estaben en territorio portugués, y, en consecuencia, exigirle su desocupación. A todo se prestaba el simple de Fernando. Pra un hallazgo semejante, pocos artículos hubieran bastado, en verdad; pero se hacia menester ahora determinar con claridad qué era quanto possía Portugal en América, para, de tal modo, dejar bien asentados los límites y asegurar a perpetuidad el derecho de cada uno. Es fama que para tal determinación, la corte de Madrid y son palabras del Marqués do Crimaldi, que bien averiguado lo tendria - 'tuvo la increíble condescendencia de ajustar el tratado de límites con arreglo a un mapa portugués manuscrito que suministró para el intento el propio ministerio lusitano'. Así salió aquel pacto desdichado u así fueron los resultados funestos que produjo...."31

Mas as críticas não se situam apenas na forma assumida pela expansão portuguesa, nem se referem tão somente a ausência de documentação de origem espanhola (adiante será vista esta questão), mas à negação dos próprios princípios em que se fundamentava o Tratado:

"El Tratado no dejaba, en todo, las cosas como estaban, ni mucho menos. Esto era el principio, el 'uti possidetis', el 
'comoposeéis'. Pero España llevaba su obsequiosidad hasta ceder territorios que no habían sido ocupados nunca por Portugal y la corte lusitana cedía en cambio para siempre a la corona de España, la Colonia del Sacramiento, fundada en territorio español y en circunstancias harto conocidas."

"Estos grandes donativos hacían dueños a los Portugueses de las provincias de Santa Catalina y Río Grande, y de una parte de las reducciones jesuíticas."

"Es decir que, a todos los territorios ocupados por la corona de Portugal en Amazonas y Mato Grosso, agregabanse ahora, por cesión expres a de la corona de España (y aquí se dejaba de lado el 'uti possidetis', como se habían hecho a un lado las líneas meridianas), dilatados territorios del sur, que de hecho y de derecho le pertenecían."32

Se esse é o julgamento atual, quando cerca de dois séculos já decorriam da elaboração do Tratado, muito mais veemente deve ter sido a repulsa com que o mesmo foi recebido na época.

"El pacto no tardó mucho en ser conocido en Buenos Aires, y aun se asegura por cronistas autorizados, que antes de poner la firma sus regios autores habían llegado noticias sobre lo que estimábase más fundamental, vale decir la devolución de la Colonia y la entrega do los siete pueblos de las Misiones Orientales.

"Cosa naturalíssima parece que la noticia produjera pésima impresión y no solamente a los jesuitas (a quienas para nada se consultó, como no se consultó el Consejo de Indias) sino a la problación de las distintas gobornaciones. El Deán Funes, que vivió en época cercana al tratado de permuta (nasció en 1740), pudo haber recogido en la tradición oral cierta frase de su 'Historia' en que se pone de relievel en aspecto más odioso de las famosas 'cesiones': 'para sostener la licitud de esta concesión - dice el Deán - era preciso echar el velo del olvido sobre lo derecho de los indios para no ser tratados como un rebaño de bestias que se pasan de unos pastos a otros'." 
Esto se hacia con los indios en oposición a buen número de declaraciones teóricas de las famosas Leyes de Indias, tan traídas y llevadas como si hubieran sido la expresión de una realidad social."

"Los jesuitas, como más interessados que nadie - y con razón en las referidas estipulaciones, así que llegaron a su noticia, dirigieran una larga exposición al virrey del Perú para solicitar que no fueran puestas en vigencia or lo menos hasta que el Rey pudiera informarse de su inaplicabilidad. El historiador Bauzá la sintetiza acertadamente asi: - "Em esa exposición notable trazábase con vigorosos tintes el quadro de la política portuguesa en el Río de la Plata, sus ambiciones y los aviesos medios de que se había valido para realizarlas. Traíanse a memoria las correrías vandálicas de los mamelucos de San Pablo, que llegaron a cautivar en veinticinco años más de trecientos mil indios; la destrucción de Ciudad Real, Villarrica y Jerez en el Paraguay la furtiva colonización de Colonia y Montevideo; las pretensiones de apropiarse la isla de Santa Catalina, como de cieto setenta leguas al sur, hacia el estrecho de Magallanes, y toda la serie de intrigas y violencias anexas e estos procederes. Ponderábanse los servicios prestados por los indios de las reducciones, tanto para rechazar a los mamelucos, como para conquistar muchos pueblos y plazas fuertes que hubieram quedade en dominio de Portugal, a no haberlos ellos redimido. Deíase que los treinta pueblos jesuíticos somabam una población de 92.835 almas, y que los seis pueblos de ellos suspechados de estar incluidos en el pacto de entrega contaban 23.733 individuos y eran los mejores de la provincia por su fertilidad, excelentes tierras y desahogo para la cria de ganado, con los cuales se mantenía el país. Y en medio de todas estas razones que el tacto político y la conveniencia general ponian en boca de los jesuítas, se leía lo seguinte, que era como el anuncio de la próxima catástrofe: "Tenemos por infalible que antes de caer en manos de Portugues, se huirán los indios a los montes a seguir la vida brutal y selvática."33

A defesa intentada pelos Jesuítas foi inteiramente contraproducente, não só por nada conseguir em favor dos mesmos, mas, ainda, por atrair contra si as disposiçòes do rei Fernando VI, a tenaz animosidade de Sebastiâo José de Carvalho e Melo e, posteriormente, do rei Carlos III, da Espanha, tendo sido essa defesa um dos pontos mais repisados para a justificação de sua expulsão do território português, na Metrópole e nas 
colônias, seguida de igual medida na Espanha e seus domínios ultramarinos. A soma de prejuízos com esta medida, dentro da América Meridional, seria inteiramente desfavorável à Espanha, pois desde as fronteiras com o atual Território de Rondônia até o Rio Grande do Sul, eram as Missões Jesuíticas os postos avançados do Império Espanhol, constituindo-se os índios das reduções e seus aliados numa fonte de preocupação constante para os fronteiriços portugueses. Expulsos os Jesuítas, muitas daquelas reduções desapareceram completamente, deixando de existir, nas proximidades da fronteira portuguesa uma força organizada, fácil e rapidamente utilizável. A Espanha anulara aqueles que tinham sido os seus mais denodados defensores e maior barreira para o avanço português.

Se na América levantaram-se vozes e protestos contra o Tratado de Madri, o mesmo se verificava na Europa. Na Espanha, mesmo antes do protesto dos Jesuítas da América, já haviam surgido as primeiras restrições ao Tratado, da parte de um membro do próprio ministério, o Marquês de la Ensenada, que, como foi visto, fora punido pelo fato de buscar o apoio do rei de Nápoles, herdeiro do trono espanhol, que logo se manifestou inteiramente contrário ao Tratado. Dos círculos da corte o descontentamento baixou às camadas populares que responsabilizavam a raínha D. Bárbara, filha de D. João V, de Portugal, pela sua participação nas negociações do Tratado, participação que, aliás, fora ativa e tenaz. A vingança manifestou-se, quando, por ocasião do seu falescimento, foi conhecida a elevada quantia que legara à sua família portuguesa, e expressou-se pelos seguintes versos:
"La estéril reina murió, solo preciosa em metales:
España engendró caudales para la que no engendró.
Bárbara desheredó a quien la herancia le ha dado, y si la Parda no ha entrado a suspenderle la uña todo lo que el rey acuña se trasladara al cuñado." 34

Mesmo em Portugal levantavam-se as vozes contra o Tratado. Desta, a mais ilustre foi a de Antônio Pedro de Vasconcelos, que por 27 anos governara a Colônia do Sacramento e que a defendera heroicamente 
durante o assédio de 1735 a 1737. Apontava Vasconcelos o perigo que, do ponto de vista da defesa militar, ocorreria para o Brasil e para a região das minas em virtude da entrega daquela praça. Destacava também a traição cometida contra o sangue português generosamente derramado parạ defendê-la. Escapavam-lhe as vantagens incontestáveis do acordo, mas tinha, pelo seu passado, o direito de manifestar-se contra, coerente com a resistência que opusera pelas armas e, agora, opunha pela palavra. Suas razões eram dignas. Mas, juntamente, elevavam-se as vozes de numerosos comerciantes portugueses e especialmente, ingleses:

"Também os negociantes portugueses e ingleses, assinala Rio Branco, interessados no comércio da Colônia do Sacramento, levantavam grandes clamores contra a ajustada entrega desse posto e cidade aos espanhóis". ${ }^{35}$

Não era tanto o comércio regular, mas o contrabando que por ela se processava que despertava essas manifestações de inconformidade, por razões muito menos nobres que as de Vasconcelos.

Assinado o Tratado de 13 de Janeiro e, pouco depois, retificado pelos dois soberanos, recebeu o primeiro golpe seis meses após pelo falecimento de D. João V. Subiu ao trono D. José I, que logo chamou para o seu ministério Sebastião José de Carvalho e Melo, posteriormente Conde de Oeiras e Marques de Pombal, desafeto de Alexandre de Gusmão, que fora o mentor e alma do Tratado.

Acusações de toda a espécie abateram-se contra o antigo secretário particular de D. João V, inclusive as de traidor de Portugal e de vendido aos espanhóis.

Ainda que seja para lamentar essa incompreensão contra uma das mais ilustres figuras daquele tempo, para a História estas injúrias foram altamente benéficas. Alexandre de Gusmão resolveu defender sua obra e sua pessoa, e assim é-nos possível compreender o pensamento e os objetivos que se consubstanciaram no Tratado de 1750, mas, ainda, surge nítida a estatura do estadista.

Assim resume Jaime Cortesão os objetivos que Alexandre de Gusmão procurou assegurar no Tratado de Madri, conforme sua resposta ao libelo de Antônio Pedro de Vasconcelos:

"1 - Equilibrar, em obediência aos interesses próprios e aos alheios as soberanias portuguesa e espanhola, pela 
partilha das bacias do Amazonas e do Prata, atribuindo, na sua maior parte, a primeira, a Portugal, e a segunda, à Espanha.

"2 - Reservar à soberania portuguesa os planaltos auríferos e diamantíferos, braço transversal da cruz esquemática do Brasil, e coração da ilha-continente, com as grandes vias fluviais de acesso.

“3 - 'Dar fundo grande e competente', conforme a sua própria expressão na resposta ao Brigadeiro Antônio Pedro de Vasconcelos, ao Brasil austral, para proteger a estrada mineira, as monções e assegurar às regiões das Minas os recursos pecuários do Rio Grande do Sul.

“4 - 'Arredondar e segurar o país' conforme aquela mesma resposta, ou seja realizar a Ilha-Continente e dar-lhe viabilidade orgânica.

"5 - Como conseqüência lógica dos dois últimos objetivos, criar no extremo-sul uma fronteira estratégica que se pusesse a qualquer tentativa espanhola de flanquear o Brasil Meridional, na sua parte mais vulnerável." 36

Complementando a síntese de Jaime Cortesão, as instruções do Próprio Alexandre de Gusmão para a contraproposta portuguesa, na fase de negociações do Tratado de Madri:

“1 - Celebrar um ajuste definitivo e não transitório, assinalando balisas tâo claras que excluam toda a contenda no futuro.

"4 - Regular os respectivos limites pelas balisas mais aparentes de Rios ou Montes, ainda que seja com desfalque de uma ou outra parte, para cortar a raiz a toda a disputa no futuro"37

Se a resposta a Antônio Pedro de Vasconcelos é posterior ao Tratado, ainda que haja entre ambos uma perfeita identidade, os pontos para a contraproposta são anteriores ao mesmo, não podendo ser imaginadas depois para justificação de conduta, mas todos eles se completam, explicam, esclaressem.

Assim o mentor do Tratado de Madri, em consonância com a política de paz de $\mathrm{D}$. João $\mathrm{V}$, desejava aproveitar aquele momento favorável, em que o trono espanhol estava ocupado por um rei de iguais 
sentimentos, para lançar as bases de uma política capaz de criar condições para um convívio pacífico nas colônias, que não exigisse uma sangria continuada de seus filhos para a sustentação das guerras coloniais. Ao lado desta preservação do elemento humano haveria também economia de recursos, pois as lutas coloniais reclamavam importâncias excessivamente grandes, capazes de desequilibrar inteiramente as finanças do reino. Era necessário que as negociações pudessem conduzir a um resultado "definitivo e não transitório", com um traçado claro de fronteiras, utilizando, sempre que possível, acidentes geográficos, que pudessem excluir, na maioria dos casos, qualquer dúvida de interpretação.

Se o ideal era alto e nobre, não fugia à realidade. Era fundamental, para o Brasil, ter assegurado meios de defesa. Se a região que poderia apresentar maior vantagem para uma ocupação era a região das minas, o planalto aurífero era necessário assegurar a posse dos meios de acesso. Assim o interesse em conservar os rios amazônicos de comunicação com o planalto aurífero de Mato Grosso, através da navegação exclusiva do Rio Guaporé. Este domínio da Amazônia representava a segurança também no acesso pelo Tocantins à região goiana de mineração. Garantida a região pelo norte, pelo oeste, a Capitania de Mato Grosso seria o anteparo para a região mais rica de Minas Gerais. Pelo sul, a Colônia do Sacramento, além de não oferecer condições reais de manutenção, transformava-se numa fonte constante de atritos com as colônias do Prata. Sua missão fora cumprida à sombra da mesma, desenvolvera-se a ocupação do Rio Grande de São Pedro e a colonização de Santa Catarina, tratava-se agora de ampliar a fronteira, com o duplo resultado de facilitar a defesa e garantir a posse de parte substancial do gado, necessário para o abastecimento do centro. Desta maneira, compreende-se o interesse pela posse das Missões, assegurando a vigilância de um dos caminhos de possível penetração, o Rio Uruguai. Se dentro do conceito jurídico, não se compreende a soberania sem uma delimitação clara de fronteiras, a obra de Alexandre de Gusmão através do Tratado de Madri, reveste-se de extraordinária importância, não só pela fixação clara dos princípios que norteariam essa delimitação, mas com a preocupação de estabelecer logo Comissões de Demarcação, que realizariam o verdadeiro objetivo do Tratado.

Assim a acusação de Antônio Pedro de Vasconcelos, do enfraquecimento da defesa em conseqüência da entrega da Colônia do 
Sacramento, pecava pela base. Anulados os pontos de atrito, dominados os pontos estratégicos, asseguradas as vias de acesso, aumentavam consideravelmente as possibilidades e as condições de defesa.

As vozes, que se elevaram contra o Tratado de Madri, mostram que o objetivo visado não seria atingido sem uma continuidade de esforços $\mathrm{e}$ a superação de um grande número de obstáculos. Essas dificuldades foram tão grandes que resultaram na suspensão do mesmo e sua anulação pelo Tratado de El Pardo. Contudo, a semente lançada frutificara. A busca de solução diversa ou de outros critérios resultou completamente improfícua e, passado um quarto de século marcado por desentendimentos, voltaram a imperar os princípios diretivos do Tratado de Madri, na redação do Tratado de Santo Ildefonso, ponto de partida do delineamento definitivo das fronteiras do Brasil. Não foi improfícuo o Tratado de Alexandre de Gusmão, pelo contrário, resultou numa contribuição duradoura para o Direito Internacional Público.

Dificuldade capital durante as negociações que precederam a assinatura do Tratado foi a falta de documentação cartográfica.

Esta insuficiência de informações cartográficas é testemunhada pela carta que, em 8 de fevereiro de 1748, Alexandre de Gusmão dirigiu ao embaixador Tomás da Silva Teles, ao remeter, de Lisboa, uma Carta Geográfica, com as indicações dos limites sugeridos por Portugal, carta que viria a ser denominada "Mapa das Cortes".

"Entretanto, para habilitar o Embaixador a interpretar as linhas do 'Plano', indica-lhe Gusmão as peças cartográfias em que se baseou:

“1ํ) 'O mapa que já remeti a V. Excia. feito pelo Padre Diogo Soares, por ser homem inteligente, e ter feito as observações sobre os mesmos lugares', desde 'Colônia, até Santos, e no interior da Lagoa Mirim, Rio de São Pedro e Curitiba'.

" $\left.2^{\circ}\right)$ Para o interior do rio Uruguai, 'supomos bastantemente ajustado o mapa que anda no tomo 28 das Lettres Edifiantes'.

" 3 ํ) O melhor mapa que temos do caminho de São Paulo a Cuiabá, 'é o que mandou fazer Gomes Freire de Andrade e também se remeteu já a V. Excia'. 
" $\left.4^{\circ}\right)$ De Mato Grosso até o rio das Amazonas, não tem saído à luz mais que uma pequena 'Cartas das Missões dos Moxos no tomo 12 da sobredita obra'.

“5) Do rio Amazonas não há até agora carta mais exata que a de Condamine impressa na sua viagem.."38

Não obstante o número relativamente grande de engenheiros já enviados de Portugal para o Brasil, a multiplicidade das funções de que estavam encarregados prendia-os comumente às sedes, resultando daí que os trabalhos de elaboração de plantas de fortificações, igrejas ou outros edifícios, absorvia seu tempo, impossibilitando o trabalho minucioso e demorado do levantamento cartográfico regional, que, verdadeiramente, só se iniciou, no Brasil, com a vinda dos "padres matemáticos" e, paulatinamente, desenvolvida depois.

As próprias dificuldades surgidas com esta falta, durante as negociações do Tratado de Madri, levaram o rei D. João V a buscar uma solução para o problema. Não dispondo Portugal de número suficiente do elementos capazes para mobilizar para esse trabalho, que compreenderia o levantamente cartográfico de toda a nossa fronteira terrestre, impunhase a contratação de elementos capazes em toda a Europa, onde fosse possível encontrá-los.

Ainda no fim do governo de D. João V, já estavam contratados em Portugal Miguel Ângelo Blasco, Carlos Inácio Reverend, Gaspar Joâo Gerardo de Cronsfeld, João André Schwebel, José Maria Cavagna, Henrique Antônio Galluzzi, Adão Wentzel Hestcko, Paulo Rorich, Manuel Gotz e N. Hatton. ${ }^{39}$ Seria, entretanto, já no governo de D. José I, que o decreto conferindo-lhes postos militares e ficando-lhes os direitos e obrigações, foi assinado com data de $1^{\circ}$ de outubro de 1750 . Ainda que o mesmo admita que possam trabalhar no reino, a maior parte das indicações mostram claramente que a finalidade do contrato ligava-se aos trabalhos de levantamento cartográfico na América:

"Que serão obrigados a servir-me neste Reino e na América, aonde forem mandados por mim, ou pelos meus Governadores, a tirar Cartas Geográficas do país, ou a qualquer outro emprego da sua profissão; Que esta obrigação durará a cada um dos sobreditos cinco anos desde o dia em que chegarem à América, passando o qual tempo ficarāo desobrigados para poderem (se quiserem) tornar para a 
Europa, e para os países donde agora vieram; Que enquanto estiverem nesta cidade e nos portos do Brasil se sustentarão do seu soldo, mas indo em expedição do meu serviço na América, desde o dia que se puserem a caminho se lhes farão por conta da minha Real Fazenda toda as despesas de sustento, conduções e gente de serviço, e se lhes subministrarão os instrumentos necessários para as operações que se lhes encarregarem; Que acabadas estas, e tendo-as executado com satisfação se quiserem persistir no meu serviço, se lhes serão continuados os mesmos postos e soldos, ou nos meus estados da América, ou neste Reino; Que o transporte para a América e o retorno daqueles Estados para este Reino se lhes fará à custa da minha Fazenda, e querendo tornar para os ditos países, donde agora vieram, lhes mandarei dar ajudas de custo com patentes conforme as suas graduaçōes, para poderem fazer; Que se na execução das ditas expedições do meu serviço contraírem enfermidades, ou outros impedimentos que os inabilitarem, lhes concederei a reforma nos mesmos postos que tiverem, com a metade do soldo enquanto viverem;..."40

O número parecia ainda pequeno. Outro decreto (30-12-1750) acrescenta mais um nome, o de Joâo Bartolomeu Havelle, e especifica claramente que deverão seguir para os Estados da América para "formar cargas geográficas das demarcações". Algum tempo depois (antes de maio de 1751) a lista apresentava-se substancialmente aumentada, compreendendo alemães, holandeses, suiços, franceses e italianos, além de portugueses. Ao lado de numerosos engenheiros aparecem seis astrônomos, sendo quatro deles padres da Companhia de Jesus e seis cirurgiões.

Os estrangeiros eram os seguintes: Miguel Ângelo Blasco, João Bartolomeu Havelle, João André Schwebel, Gaspar João Gerardo de Cronsfeld, Carlos Inácio Reverend, José Rollen Wandreck, Henrique Antônio Galluzzi, José Maria Cavagna, Filipe Frederico Sturm, João Inácio Piton, Adam Leopoldo de Breuning, Adāo Wentzel Hesteko, Miguel Gotz, Inácio Hatton, Paulo Rorich, Guilhérme de Bassines, aos quais se acrescentavam os portugueses: José Custódio de Sá e Faria, Sebastião José da Silva, Francisco Xavier Pais de Menezes e Bragança, Gregório Rebelo Guerreiro Camacho e Guilherme Joaquim Pais de Menezes e Bragança, todos com postos de engenheiro desde coronel até ajudante. Como astrônomos vinham: P. Bartolomeu di Panigai, P. Bartolomeu Pincete, P. Stephano Bramieri, P. Xaverio Haller, Dr. Agostinho Brunelli e Dr. Michele Ciera. ${ }^{41}$ 
Ainda dois anos permaneceriam no reino, vindo para o Brasil, uns subordinados ao governo do Rio de Janeiro, outros dirigidos ao Estado do Grão Pará e Maranhão.

Para o Grão Pará e Maranhão foram enviados: o P. Inácio Strent Martony, o Dr. João Ângelo Brunelli, os engenheiros Sebastião José da Silva (Sargento-mor), João André Schwebel, Gaspar Gerardo Cronsfeld, Gregório Rebelo Guerreiro Camacho (Capitães), Henrique Antônio Galluzzi, Adam Leopoldo de Breuning, Filipe Sturm (Ajudantes), Miguel Gotz (Tenente), Antônio Landi (Desenhista) e os cirurgiōes Daniel Panck, Antônio de Matos e Domingos de Sousa, que deveriam receber pela Provedoria do Pará, segundo a ordem de 23 de maio de 1753.

Um pouco antes já havia seguido a primeira das turmas com destino ao Rio de Janeiro, entre os quais Miguel Ângelo Blasco e José Custódio de Sá e Faria. ${ }^{42}$

$\mathrm{O}$ cuidado e minuciosidade com que foi preparada a expedição causa admiração e espanto. Nada parece ter sido esquecido ou deixado ao acaso. Além de mantimentos, material de acampamento, armas e munições, material de cozinha e mesa, vieram para o Pará 33 caixas contendo material para desenho, instrumentos para os levantamentos topográficos e astronômicos, além de 95 tomos de obras diversas de matemática, física, geografia, viagens, tábuas astronômicas, tábuas de logarítmos, tábuas de senos, tangentes e secantes. Tudo, enfim, que pudesse permitir aos integrantes de seu trabalho, em condições, até mesmo, de relativo conforto. ${ }^{43}$

Mesmo que os problemas surgidos resultassem na suspensão dos trabalhos e, depois, na própria anulação do Tratado de Madri, foi de extraordinária importância a vinda de tantos engenheiros e cartógrafos para o Brasil. Grande número deles permaneceu na América mais tempo do que o inicialmente ajustado, sendo que diversos aqui se fixariam definitivamente. $\mathrm{O}$ impulso dado aos levantamentos cartográficos foi verdadeiramente notável, causando admiraçāo, pela quantidade e pela qualidade, os trabalhos dispersos hoje por diversos arquivos oficiais ou particulares.

Desta maneira, o Tratado de Madri foi o primeiro passo, mas passo decisivo, na fixação das nossas fronteiras no plano jurídico e o marco inicial do trabalho paulatino de sua demarcação. 


\section{NOTAS}

1. BRAZĀO, Eduardo. História Diplomática de Portugal. ob. cit. v. 1. p. 270 ss.

2. MARQUES, A. H. de Oliveira. História de Portugal. 2. ed. Lisboa: Ágora, 1973.v. 1. p. 456-7.

3. CORTESÃo, Jaime. Alexandre de Gusmão e o Tratado de Madri, Rio de Janeiro: Ministério das Relaçōes Exteriores, 1952. t. 1, Parte I. p. 64-5.

4. Id. ibidem. p. 67.

5. SERRÃO, Joel, (dir). Dicionário de História de Portugal. Porto: Figueirinhas, 1971. v. 2. p. 285.

6. CORTESÃO, J., ob. cit. p. 286.

7. Id. ibidem. p. 289.

8. Id. ibidem. p. 291.

9. Id. ibidem. p. 447.

10. Id. ibidem. p. 93.

11. Carta de Diogo de Mendonça Corte Real, de 14/1/1722. In CORTESÃO, J., ob. cit. t. 1, Parte III. p. 244-5.

12. Carta de D. Luís da Cunha para Marco Antônio de Azevedo Coutinho, de 14/9/1736. In CORTESÃO, J., ob. cit. t. 1, Parte III. p. 290.

13. SOARES, José Carlos de Macedo. Fronteiras do Brasil no regime colonial. Rio de Janeiro: José Olympio, 1939. p. 131-2.

14. Id. ibidem. p. 141.

15. Id. ibidem. p. 145.

16. Id. ibidem. p. 146.

17. Id. ibidem. p. 146.

18. Id. ibidem. p. 147.

19. Id. ibidem. p. 150 e 155 .

20. Id. ibidem. p. 152.

21. Id. ibidem. p. 154.

22. Id. ibidem. p. 156.

23. TERRENO, José. História de España, Barcelona: Sopena, 1971. p. 339.

24. AZEVEDO, João de Sousa. Parecer de João de Souza Azevedo (Tratado de 1750), comentários e notas de CORREA FILHO, Virgílio. In Revista do Instituto Histórico e Geográfico Brasileiro, Rio de Janeiro, 1943. v. 179. p. 185.

25. Id. ibidem. p. 186.

26. Id. ibidem. p. 205.

27. Id. ibidem. p. 204.

28. Id. ibidem. p. 204.

29. Id. ibidem. p. 205.

30. Id. ibidem. p. 203.

31. BUSANICHE, José Luis. História Argentina. Ob. cit. p. 221-2.

32. Idem ibidem. p. 222-3.

33. Idem ibidem. p. 224-6.

34. BUSTAMANTE, C. Perez. Síntesia de história de España. 9. ed. Madri: Atlas, 1953. p. 197.

35. CARVALHO, Estevão Leitão de. Segundo Centenário de Tratado de Madri. In Revista do Instituto Histórico e Geografico Brasileiro. Rio de Janeiro, 1950. v. 206, p. 233.

36. CORTESÃo, J. Alexandre de ... Ob. cit. t. 2, Parte I. p. 261.

37. Id. ibidem. p. 285. 
38. CORREA FILHO, Virgîlio. Vicissitudes do Tratado de Madri. In Revista do Instituto Histórico e Geográfico Brasileiro. Anais do Congresso Comemorativo do Bicentenário da Transferência da sede do Governo do Brasil de Salvador para o Rio de Janeiro. Rio de Janeiro, 1963. v. 2, p. 306-5; CORTESĀO, J. Alexandre de ... Ob. cit. t. 2, Parte I, p. 327.

39. VITERBO, Francisco M. de Sousa. Expediçōes cientifico-militares enviadas ao Brasil. Ob. cit. v. 1 , p. 5 .

40. Id. ibidem. p. 51.

41. Id. ibidem. p. 53-4.

42. Id. ibidem. p. 85 .

43. Arquivo do Instituto Histórico e Geográfico Brasileiro, n. 1, p. 1-12: Relação do preparo, mantimentos, instrumentos matemáticos e livros que no ano de 1753 , da Corte se remeteram à Cidade do Pará para servirem na expedição das demarcações ajustadas pelo Tratado de Limites no ano de 1750, entre as Cortes de Portugal e Espanha.

\section{BIBLIOGRAFIA}

\section{1 - Obras Gerais}

\section{Brasil}

ABREU, J. Capistrano. Capítulos de História colonial. Rio de Janeiro: Soc. C. de Abreu, 1964.

ACCIOLY, Hildebrando. Limites do Brasil. São Paulo: Nacional, 1938.

AGUIAR, Pinto de.Aspectos da economia colonial. Salvador: Progresso, 1957.

ALMEIDA, Manuel Lopes de. Notícias históricas de Portugal e Brasil (1715-1750). Coimbra: Coimbra, 1961.

ANTUNES, de Paranhos, Limites do Brasil Meridional. in Revista do Instituto de Geografia e História Militar, Rio de Janeiro, v. 14, p. 55-71, 1950.

BEVILÁQUA, Clóvis. Limites do Brasil. In Revista Militar, Rio de Janeiro, v. 4, 1902.

BOITEAUX, Lucas Alexandre. Bosquejo histórico sobre a nossa Política Nacional e Continental (1494-1765). In Anais Quarto Congresso de História do Brasil. Rio de Janeiro, 1949. v. 7. p. 15.

BRUNO, Ernani Silva. História do Brasil. Geral e Regional, São Paulo: Cultrix, 1966.

CALMON, Padre. História da Civilização Brasileira. São Paulo: Nacional, 1937. . História do Brasil. São Paulo: Nacional, 1939-1956. 5v.

CALÓGERAS, João Pandiá. Formaçāo histórica do Brasil. 7. ed. São Paulo: Nacional, 1967.

CARVALHO, Carlos Delgado de. História Diplomática do Brasil. São Paulo: Nacional, 1959.

CARVALHO, Leitão de. Segundo centenário do Tratado de Madrid. In Revista do Instituto Histórico e Geográfico Brasileiro, v. 206, p. 212-34, 1950.

CORREAA FILHO, Virgilio. Aspectos do rompimento da linha de Tordesilhas. In Anais Quarto Congresso de História do Brasil. Rio de Janeiro, 1949.v. 7, p. 167.

. Formaçāo Geográfica do Brasil. In Revista do Instituto Histórico e Geográfico Brasileiro, v. 212, p. 174-90. 1951.

- Fronteira Meridional (frustrações de tentativas demarcatórias), In Anais do Congresso Comemorativo do Bicentenário de Transferência da Sede do Governo do Brasil da Cidade do Salvador para o Rio de Janeiro. Rio de Janeiro, 1963. v. 2. p. 147-230.

. Vicissitudes do Tratado de Madrid. In Anais do Congresso Comemorativo do Bicentenário de Transferência da Sede do Governo do Brasil da Cidade do Salvador para o Rio de Janeiro. Rio de Janeiro, 1963. v. 2. p. 287-349. 
CORTESÃo, Jaime. Alexandre de Gusmão e o Tratado de Madrid, Rio de Janeiro: Ministério das Relaçōes Exteriores, 1952. 9v.

. Expansão Territorial e Povoamento do Brasil. In BAIÃO, A.E.S. História de expansão portuguesa no Mundo. Lisboa. v. 3, p. 125-42.

- Relações entre a Geografia e a História do Brasil. In BAIÃO. A.E.S. História da expansão portuguesa no Mundo. Lisboa. v. 3. p. 7-30.

COSTA, Nélson Nunes. Bicentenário do Bobadela. In Revista do Instituto Histórico e Geográfico Brasileiro, Rio de Janeiro, v. 257, p. 163-5, 1962.

. Gomes Freire, Vice-rei. In Revista do Instituto Histórico e Geográfico Brasileiro, v. 255, p. 363-365. 1962.

DEFFONTAINES, Pierre. Geografia Humana do Brasil, 2. ed. Rio de Janeiro: Casa do Estudante do Brasil, 1952.

DIAS, Demóstenes de Oliveira. Alexandre de Gusmão e o Tratado de Madrid. Separata da Revista Casa da Moeda. s.l.d.

DIÉGUES JÚNIOR, Miguel. As companhias privilegiadas no comércio colonial. In Revista de Historia, v. 1, p. 309, 1950.

DORMAS FILHO, Joăo. Aspectos da economia colonial. Rio de Janeiro: Biblioteca do Exército, 1958.

FERREIRA, Vieira. Legislação Portuguesa relativa ao Brasil. In Revista do Instituto Histórico e Geográfico Brasileiro, t. 105, v. 159, p. 201-29, 1929.

FRANÇA FILHO, Ernesto Ferreira. Limites do Brasil. In Revista do Instituto Histórico e Geográfico Brasileiro, t. 33, II parte, p. 213-36, 1870.

FREITAS, Gustavo de. A companhia geral do comércio do Brasil (1649-1720). In Revista de História, v. 2, p. 307-28, 1951; v. 3, p. 85-110 e 313-4, 1951.

GALANTE, Pe. Rafael M. História do Brasil. 2. ed. São Paulo: Duprat, 1911. v. 2.

HOLANDA, Sérgio Buarque de. História da civilização brasileira à época colonial. 2. ed. São Paulo: Difusão Européia do Livro, 1963. 2v.

LEITÃO, Rubem Andersen. A importância do fundo real erário para a história do Brasil. Lisboa: Academia Portuguesa de História, 1072.

LEITE, Pe. Serafim. Segundo centenário do cartógrafo Padre Diogo Soares. In Revista do Instituto Histórico e Geográfico Brasileiro, v. 201, p. 84, 1948.

LIMA, Felício. Limites do Brasil. In Revista do Instituto de Geografia e História Militar do Brasil. v. 14, p. 41-53, 1950.

LOBO, Eulália Maria Lahmeyer. Administração colonial luso-espanhola nas Américas. Rio de Janeiro, 1952.

MAGALHÃES, Basílio de. Expansão geográfica do Brasil Colonial. 2. ed. São Paulo: Nacional, 1952.

MAURO, Frèdèric. L'Économic Européenne et L'Atlantique Sud aux XVII et XVIII Siècles (Brésil et Portugal). In Actas do $\mathrm{V}$ Colóquio Internacional de Estudos Luso-Brasileiros, Coimbra, 1965. v. II. p. 7-16.

MELO, Cláudio de Oliveira. Gomes Freire de Andrade - Eminente Estadista da época colonial. In Revista do Instituto Histórico e Geográfico do Pará, v. XVI/XVII, p. 193-7, 1969-1970.

MENDONÇA, Marcos Carneiro de. O pensamento da metrópole portuguesa em relação ao Brasil. In Revista do Instituto Histórico e Geográfico Brasileiro, v. 257, p. 43-61, 1962.

MENDONÇA, Renato de. História da politica exterior do Brasil. Do Periodo Colonial ao Reconhecimento do Império, 1500-1825. México: Instituto Panamericano de Geografia e História, 1945, t. I.

MORENO, Diogo de Campos. Livro que dá razão do Estado do Brasil. Rio de Janeiro: Instituto Nacional do Livro, 1968. 
MÚRIAS, Manuel Maria. A marcha do Brasil para o Prata. In Anais Congresso do Mundo Português. Lisboa, 1940. v. X, t. II. p. 417-27.

NEIVA, Artur Hehl. Povoamento do Brasil no Século XVIII. In Revista de História. v. 4, p. $379-86,1952$.

NEMÉSIO, Vitorino. Portugal e o Brasil na História. Rio de Janeiro: Imprensa Nacional, 1952.

NORTON, Luís. A colonização porguguesa no Brasil, 1500-1550. México, 1941.

PEIXOTO, Afrânio. História do Brasil. 2. ed. São Paulo: Nacional, 1944.

PINTO, Antônio Pereira. Limites do Brasil (1493-1851). In Revista do Instituto Histórico e Geográfico Brasileiro.

POMBO, José Francisco da Rocha. História do Brasil. Rio de Janeiro: W.M. Jackson, 1947. 5v.

PRADO JÚNIOR, Caio. História econômica do Brasil. São Paulo: Brasiliense, 1945.

REIS, Arthur Cézar Ferreira. A Contribuição Portuguesa na Formação da Nacionalidade Brasileira. In Revista do Instituto Histórico e Geográfico Brasileiro, v. 249, p. 385-400, 1960.

REIS, Arthur César Ferreira. O Governo de Gomes Freire de Andrade. In Estudos Históricos, Marilia, n. 3-4, p. 235-254, dezembro, 1965.

REPARAZ, Gonçalo de. O Brasil no Império Espanhol. In Revista do Instituto Histórico e Geográfico de São Paulo, v. 20, p. 103 e 818, 1915.

RIBEIRO, João. História do Brasil. Rio de Janeiro: Liv. São José, 1954.

RIO BRANCO, Barão do. Efemérides brasileiras, Rio de Janeiro: Ministério das Relações Exteriores, 1946.

RIO BRANCO, Barão do. História do Brasil. Rio de Janeiro: Instituto Rio Branco, 1958.

ROCHA, Artur Pinto da. História Diplomática do Brasil. In Revista do Instituto Histórico e Geografico Brasileiro, t. 77, II parte, p. 223.

S/AUTOR. Sistema Preventivo da Metrópole contra o Brasil. In Revista do Instituto Histórico e Geográfico Brasileiro, t. 46, I parte, p. 239-40.

SALVADOR, Frei Vicente do. História do Brasil (1500-1627), 4. ed. São Paulo: Melhoramentos, 1954.

SIMONSEN, Roberto C. História da Economia do Brasil (1500-1820) 3. ed. São Paulo: Nacional, 1957.

SOARES, José Carlos de Macedo. Fronteiras do Brasil no Regime Colonial. Rio de Janeiro: José Olympio, 1939.

SOUTHEY, Robert. História do Brasil. 3. ed. São Paulo: Obelisco, 1965. 6v.

VÁRIOS, Dicionário Histórico, Geográfico e Etnográfico do Brasil. Rio de Janeiro: Imprensa Nacional, 1922. 2v.

VARNHAGEN, Francisco Adolfo. História Geral do Brasil, 5. ed. São Paulo: Melhoramentos, $1956.5 \mathrm{v}$.

VASCONCELLOS, Diogo de. Linhas Gerais da Administração Colonial. Como se exercia. O vice-rei, os capitães-generaes, os governadores, os capitåes-mores de capitanias e os capitães-mores de ilhas e cidades. In Anais Primeiro Congresso de História do Brasil. 1916. v. 3. p. 281.

VELHINHO, Moisés. A expansão Meridional do Brasil. In Anais do Congresso Comemorativo do Bicentenário da Transferência da Sede do Governo do Brasil da Cidade do Salvador para o Rio de Janeiro. 1963. v. 2. p. 259.

VIANNA, Hélio. Estudos de História Colonial. São Paulo: Nacional, 1948. . História Diplomática do Brasil. Rio de Janeiro: Biblioteca do Exército, 1958. História do Brasil. São Paulo: Melhoramentos, 1962. 2v.

XAVIER, César Feliciano. Três décadas da evolução histórico-social da América portuguesa, culminada pela autonomia brasílica reconhecida em 1750. Alexandre de Gusmão, o Panamericanista. In Revista do Instituto Panamericano de Geografia, e História, v. 3, p. $155,1932 / 1933$. 


\section{2 - Específicos}

\section{Exército e Fortificações}

ALVES, F.; PORTELLA, J. V. Seis séculos de artilharia. Rio de Janeiro: Biblioteca do Exército, 1959.

AZEVEDO, Pedro Cordolino F. de. História militar do Brasil. Rio de Janeiro: Departamento de Imprensa Nacional, 1950/1952. 2v.

AZAMBUJA, Inácio Carneiro de. Fortificações permanentes, Rio de Janeiro: Biblioteca do Exército, 1940.

BARRETO, Anibal. As fortificações do Brasil. Rio de Janeiro: Biblioteca do Exército, 1958.

BARROSO, Gustavo. História militar do Brasil. Sã Paulo: Nacional, 1935.

CARVALHO, Leitão de. Forças Armadas. In Revista do Instituto de Geografia e História Militar do Brasil, v. 13, p. 85-113, 1948.

CAVALCANTI, Pedro de A. Organização Militar da Colônia no Século XVIII. In Anais Quarto Congresso de História do Brasil, 1949. v. 7. p. 155.

CIDADE, Francisco de Paula. O Exército Brasileiro no Período Colonial. In Anais Congresso Internacional de História da América, 1922. v. 7. p. 631-739.

\section{Santa Catarina}

BOITEAUX, Lucas. História de Santa Catarina. São Paulo: Melhoramentos, s.d.

CABRAL, Osvaldo. As defesas da Ilha de Santa Catarina no Brasil-Colônia. Rio de Janeiro: Conselho Federal/Landes, 1970.

MAGALHĀES, Basîlio. Os Bandeirantes em Santa Catarina. In Revista Trimestral do Instituto Histórico e Geografico de Santa Catarina, v. 7, p. 359-66, 1918.

TAUNAY, Afonso de E. Em Santa Catarina Colonial. In Anais do Museu Paulista. São Paulo, 1956. t. 7. p. $569-748$.

\section{Rio Grande do Sul e Colônia do Sacramento}

AMORIM, Anibal. Fortificaçōes do Rio Grande do Sul. In Revista do Instituto Histórico e Geográfico do Rio Grande do Sul, n. 66, p. 293-304, 1937.

ANTUNES, de Paranhos. Dragões de Rio Pardo. Rio de Janeiro: Americana, 1954.

BRITO, Torquato Xavier de. Memória do assédio e rendiçāo da praça (Colônia do Sacramento) em Maio de 1777. In Revista do Instituto Histórico e Geográfico Brasileiro, t. 39, II parte, p. $277,1876$.

BUSANICHE, José Luis. História Argentina. $3^{\text {a }}$ reimpresión. Buenos Aires: Solar/Hachette, 1975.

CèSAR, Guilhermino. História do Rio Grande do Sul. Periodo Colonial. Porto Alegre: Globo, 1970.

. Primeiros Cronistas do Rio Grande do Sul. Porto Alegre: A Nação, 1969.

CIDADE, Francisco de Paula. Lutas ao sul do Brasil com os espanhóis o seus descendentes (1630-1828). Rio de Janeiro: Ministério da Guerra, 1948.

DOCCA, Emílio Fernandes de Sousa. História do Rio Grande do Sul. Rio de Janeiro: Organização.Simões, 1954.

DUARTE, Eduardo. Velhos Fortes. Revista do Museu Júlio de Castilhos e Arquivo Histórico do Rio Grande do Sul. v. 4, n. 5, p. 10-16, 1955. 
FERREIRA FILHO, Arthur. Historia Geral do Rio Grande do Sul (1503-1964). 3. ed. Porto Alegre: Globo, 1965.

FORTES, Joāo Borges. Rio Grande de São Pedro: povoamento e conquista. Rio de Janeiro, 1941.

. Silva Paes e a fundação do Rio Grande. In Revista do Instituto Histórico e Geográfico do Rio Grande do Sul, n. 51, p. 3, 1933.

KITZINGER, Alexandre Max. A Colônia do Sacramento. In Revista do Instituto Panamericano de História e Geografia, v. 3, 1932/1933.

LEĀO, Sebastião. Datas Rio-grandenses. Porto Alegre: Globo, 1962.

MONTEIRO, Jonathas da Costa Rege. A Colonia do Sacramento. Porto Alegre: Globo, 1937. 2v.

- Fortificações do Canal e Cidade do Rio Grande. In Anais do II Congresso de História e Geografia Sul Rio-Grandense. 1937. v. 2. p. 243-64.

NEIS, Ruben. Guarda Velha de Viamão. Porto Alegre: Sulina, 1975.

PINHEIRO, José Feliciano Fernandes, Visconde de São Leopoldo Anais da Província de São Pedro. Rio de Janeiro: MEC/INL, 1946.

PORTO, Aurélio. Os Dragōes do Rio Pardo. In Revista do Arquivo Histórico do Rio Grande do Sul e Museu Julio de Castilhos, Porto Alegre, ano 6, n. 7, 1957.

REICHARDT, Herbert Canabarro. A Colônia do Sacramento, sua projeção nos acontecimentos do Prata. In Anais do Congresso Comemorativo do Bicentenário da Transferência da Sede do Governo do Brasil da Cidade do Salvador para o Rio de Janeiro. 1963. v. 2. p. 9.

SOTA, Juan Manuel de la. Notícias históricas extraídas de la História de la República Oriental del Uruguay. In Revista Histórica, Montevideu, Archivo Histórico Nacional, t. 4, n. 10, 1911.

SOUSA JÚNIOR, Antônio de. Caminhos históricos de invasão. Campanhas militares do Sul. Rio de Janeiro: Biblioteca do Exército, 1950.

SPALDING. Dragões do Rio Grande do Sul. In Revista do Instituto Histórico e Geográfico do Rio Grande do Sul. n. 64, p. 219-49, 1936. . Gênese do Brasil Sul. Porto Alegre: Sulina, 1953.

VELLINHO, Moysés. Antecedentes da formação histórica do Rio Grande do Sul. In Província de São Pedro, Porto Alegre, n. 20, p. 195-208, s/d.

- Capitania D'El Rei. Aspectos polêmicos da formação rio-grandense. Rio de Janeiro: Globo, 1964.

. Fronteira. Porto Alegre: Globo, 1975. 